\title{
Occurrence of Holacanthus clarionensis (Pomacanthidae), Stegastes leucorus, and Stegastes acapulcoensis (Pomacentridae) at Magdalena Bay, B.C.S., Mexico
}

Arturo Hernández-Velasco ${ }^{1 *}$, Francisco J. Fernández-Rivera-Melo', Sara M. Melo-Merino ${ }^{2}$ and Juan Carlos Villaseñor-Derbez ${ }^{1,3}$

\begin{abstract}
Pomacanthids and Pomacentrids are mainly distributed in tropical and subtropical regions, and inhabit shallow rocky and coral reefs. Due to their colorful patterns and unusual body shapes, they have been widely targeted by aquarium fish trade; these species are of great commercial interest. Here we document the occurrence of one Pomacanthid (Holacanthus clarionensis), and two Pomacentrids (Stegastes acapulcoensis, and S. leucorus) north of their reported distribution range during the 2014 warm water period in the eastern Tropical Eastern Pacific. Sightings took place at Magdalena-Almejas Bay complex, located in the western margin of the Baja California Peninsula. Using a series of abiotic data for the Tropical Eastern Pacific, we created a maximum entropy model for each species and identified that high probability of occurrence at Magdalena-Almejas Bay complex was only denoted for S. leucorus. Here we report the occurrence of H. clarionensis, S. acapulcoensis and S. leucorus $70 \mathrm{~km}$, $300 \mathrm{~km}$, and $300 \mathrm{~km}$ north of the northernmost reported limits.
\end{abstract}

Keywords: Reef fish, Pomacanthidae, Pomacentridae, Zoogeography, Occurrence

\section{Introduction}

Pomacanthids (angelfishes) and Pomacentrids (damselfishes) are mainly distributed in tropical and subtropical regions, and inhabit rocky and coral reefs between 1 and $30 \mathrm{~m}$ deep; a few species range to depths of $80 \mathrm{~m}$ or more (Thomson et al., 2000; Robertson \& Allen 2008). Eschmeyer \& Fong (2015) and Nelson (2006) report a total of 89 angelfish, and 387 damselfish species distributed around the world's oceans. Along the Mexican coast, in the Eastern Tropical Pacific, registered species of this family include four angelfishes: Pomacanthus zonipectus (Gill, 1862), Holacanthus passer (Valenciennes, 1846), H. limbaughi (Baldwin, 1963), and H. clarionensis (Gilbert, 1891), and 13 damselfishes: Abudefduf troschelii (Gill, 1862), A. declivifrons (Gill, 1862), Azurina hirundo (Jordan \& McGregor in Jordan \& Evermann, 1898),

\footnotetext{
*Correspondence: jhernandez@cobi.org.mx

${ }^{1}$ Comunidad y Biodiversidad, A.C. Calle Isla del Peruano \#215 Col. Lomas de Miramar, Delicias, CP 85448 Guaymas, Sonora, Mexico

Full list of author information is available at the end of the article
}

Chromis alta (Greenfield \& Woods, 1980), C. atrilobata (Gill, 1862), C. limbaughi (Greenfield \& Woods, 1980), Hypsypops rubicundus (Girard, 1854), Microspathodon bairdii (Gill, 1862), M. dorsalis (Gill, 1862), Stegastes acapulcoensis (Fowler, 1944), S. flavilatus (Gill, 1862) S. leucorus (Gilbert, 1892) S. rectifraenum (Gill, 1862), and S. redemptus (Heller \& Snodgrass, 1903).

Due to their colorful patterns and unusual body shapes, angelfish and damselfish have been widely targeted by aquarium fish trade, thus many species are of great commercial interest. In fact, damselfishes hold the world's first place in such trade, while angelfishes are rated as fifth (Wabnitz et al. 2003). Piña-Espallargas et al. (2001) have pointed that $H$. clarionensis, S. leucorus and $S$. acapulcoensis are considered as commercially important fish in Mexico's ornamental fishery.

Internationally, $H$. clarionensis and $S$. leucorus are listed as "Vulnerable" species in the International Union for Conservation of Nature (IUCN) red list, as their already limited distribution is likely to be affected by the 
ongoing climate change, resulting in reduction of actual population sizes (Pyle et al., 2010; Allen et al. 2010a, 2010b). In addition, these three species are not listed in any appendix of the Convention of International Trade of Endangered Species of Wild Fauna and Flora (CITES). Nevertheless, at a national level the only species with a degree of vulnerability is $H$. clarionensis, listed as needing "Special protection" due to their great demand by aquarium trade industry and their limited range of distribution to the Mexican Pacific (Diario Oficial de la Federación, 2010).

In this paper we document the occurrence of $H$ clarionensis, S. acapulcoensis, and S. leucorus north of their reported range of distribution. Given the ecological and economic importance of such species, this information should be taken into account for future decisions making in conservation and management subjects.

\section{Materials and methods}

Magdalena and Almejas bays are located in the southwestern coast of the Baja California Peninsula (Fig. 1). The Magdalena-Almejas Bay complex is one of Mexico's largest lagoon systems, recognized as a Region for Conservation Priority due to its large fishing production, the representation of multiple habitats, significant fish and bird diversity, and for being an important breeding zone for gray whales and sea turtles (Galván-Magaña et al. 2000; Gardner \& Chávez-Rosales 2000; Zarate-Ovando et al., 2006). This particular region has been widely reported to be an important transition zone (an ecotone) between temperate and tropical environments, and represents one of the southernmost regions still under the influence of the California Current, where the outermost part of the bay is constantly influenced by upwelling events (ÁlvarezBorrego et al., 1975; Zaitsev et al., 2010).

Between 2010 and 2014 a total of 295 underwater ecological surveys were conducted as part of a major monitoring program of no-take marine reserves and fishing grounds in the area. Fish assemblages in five monitoring sites were surveyed using belt transects $(30 \times 2 \mathrm{~m})$, where richness and abundances were estimated by ReefCheck California certified scuba divers. Sampling effort for each year and monitoring site is presented in Table 1. The specimens of $H$. clarionensis, S. leucorus and S. acapulcoensis were only present during 2014 monitorings and were identified on the basis of the diagnostic traits present by Allen \& Robertson (1994) and Humann \& de Loach (2004).

To determine the currently accepted geographical range of the species we used specialized literature (Allen

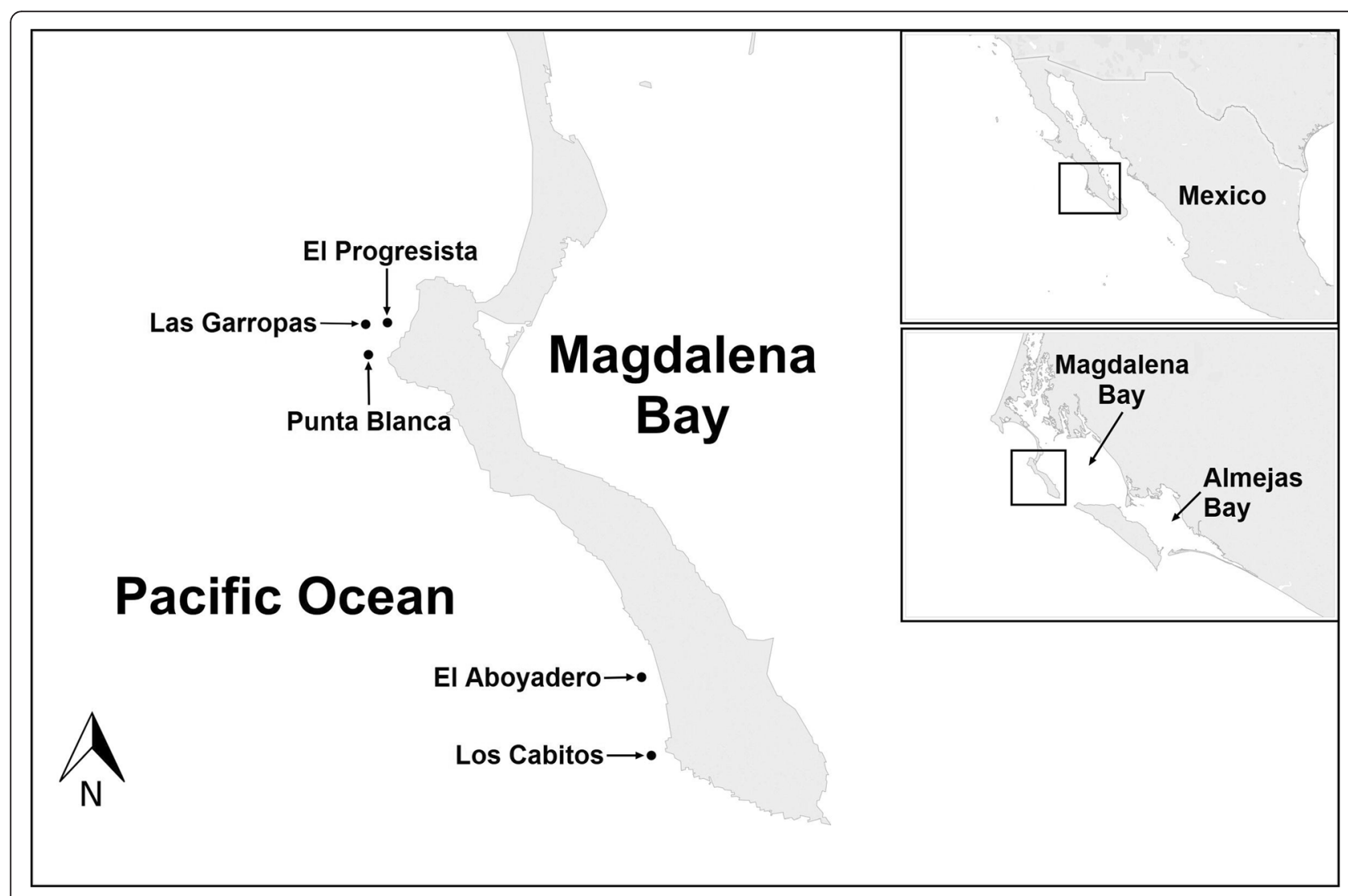

Fig. 1 Map of Magdalena and Almejas Bays. Black dots indicate monitoring sites 
Table 1 Sampling effort for five monitoring sites at Isla Magdalena from 2010 to 2014

\begin{tabular}{lccccccc}
\hline $\begin{array}{l}\text { Monitoring } \\
\text { site }\end{array}$ & \multicolumn{2}{l}{ Coordinates } & \multicolumn{5}{c}{ Year } \\
\cline { 2 - 7 } & Latitude & Longitude & 2010 & 2011 & 2012 & 2013 & 2014 \\
\hline El Aboyadero & 24.57 & -112.10 & 6 & 21 & 7 & 16 & 22 \\
El Progresista & 24.66 & -112.17 & 12 & 27 & 14 & 4 & 20 \\
Las Garropas & 24.66 & -112.18 & - & - & 12 & - & 19 \\
Los Cabitos & 24.55 & -112.10 & 6 & 18 & 10 & 6 & 13 \\
Punta Blanca & 24.65 & -112.18 & 7 & 21 & 14 & - & 20 \\
$\quad$ Total & & & 31 & 87 & 57 & 26 & 94 \\
\hline
\end{tabular}

1998; Robertson \& Allen 2008), and looked at information about specimens housed in over 20 collections of Mexico and the United States, available in the Global Biodiversity Information Facility webpage (GBIF, 2015), the Ocean Biogeographic Information System (OBIS, 2015), FishBase (Froese \& Pauly, 2014), and VerNet (2015).

We used the maximum entropy software MaxEnt ver. 3.3.3 k (Phillips et al., 2006) to develop an ecological niche model of the species on the basis of occurrence records and on yearly average, annual range, maximum and minimum surface values of a series of oceanographic factors $(9 \times 9 \mathrm{~km}$ pixel resolution). Temperature $\left({ }^{\circ} \mathrm{C}\right)$, chlorophyll a concentration $\left(\mathrm{mg} / \mathrm{m}^{3}\right)$, photosynthetic active radiation (Einstein $/ \mathrm{m}^{2} /$ day), and water

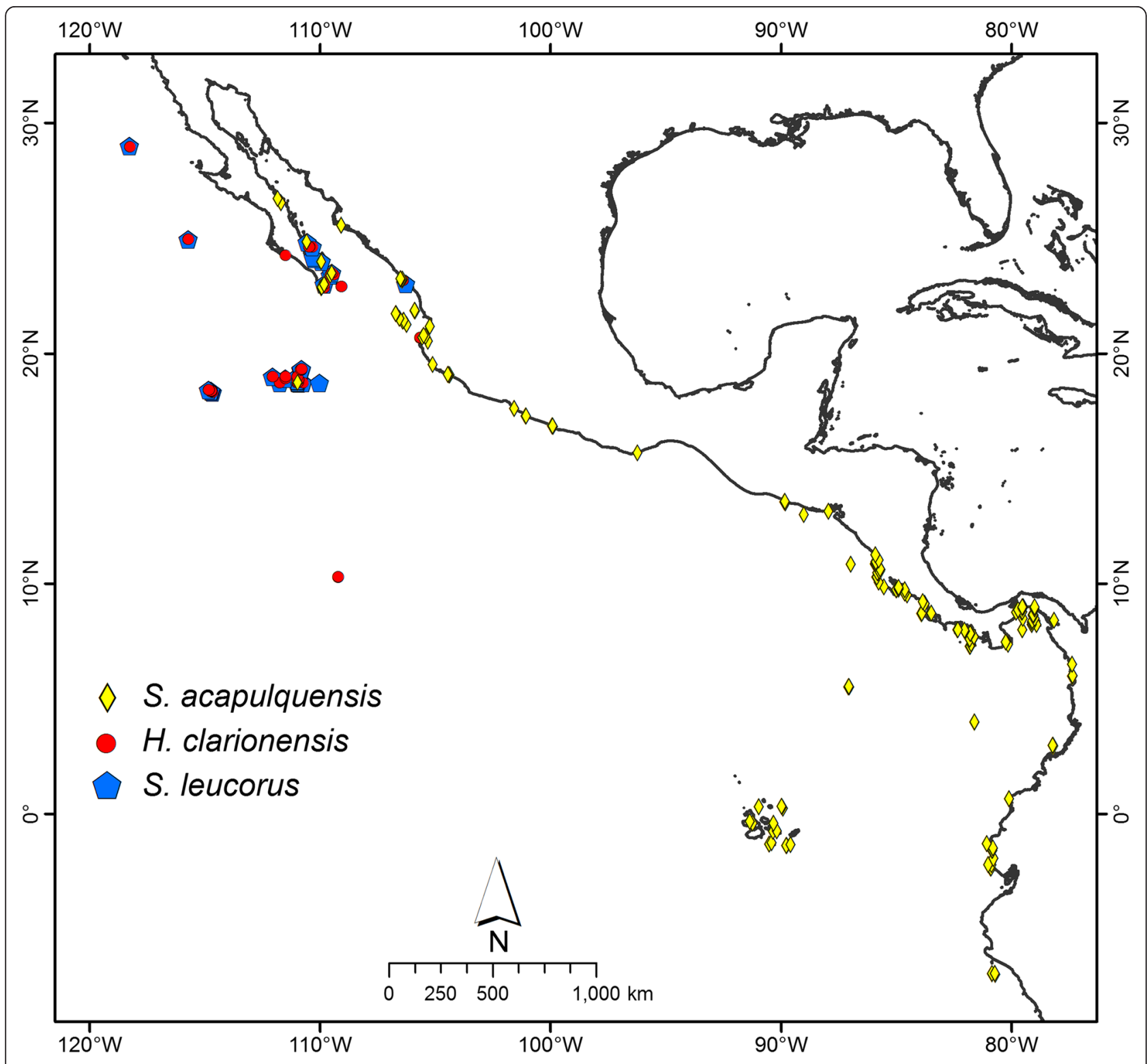

Fig. 2 Distribution of H. clarionensis, S. acapulcoensis and S. leucorus according to information of the GIF, OBIS, Fishbase, and VerNet databases 
Table 2 Previously reported northern endpoints for Holocanthus clarionensis, Stegastes acapulcoensis, and S. leucorus and records of this study

\begin{tabular}{|c|c|c|c|c|c|}
\hline \multirow[t]{2}{*}{ Species } & \multicolumn{2}{|c|}{ Northernmost limit in Baja California's Pacific Coast } & \multicolumn{2}{|l|}{ This record } & \multirow{2}{*}{$\begin{array}{l}\text { Distance } \\
(\mathrm{Km})\end{array}$} \\
\hline & Latitude $\left({ }^{\circ} \mathrm{N}\right)$ & Longitude ( $\left.{ }^{\circ} \mathrm{W}\right)$ & Latitude $\left({ }^{\circ} \mathrm{N}\right)$ & Longitude $\left({ }^{\circ} \mathrm{W}\right)$ & \\
\hline Holacanthus clarionensis & 24.25 & 111.50 & 24.55 & 112.10 & 70 \\
\hline Stegastes acapulcoensis & 22.87 & 109.95 & 24.65 & 112.18 & 300 \\
\hline Stegastes leucorus & 23.00 & 109.83 & 24.55 & 112.10 & 300 \\
\hline
\end{tabular}

transparency $(1 / \mathrm{m})$ were obtained from the Ocean Color Radiometry Online Visualization and Analysis Tool (GIOVANNI) of the National Aeronautics and Space Administration of the United States (NASA; http:// gdata1.sci.gsfc.nasa.gov/daac-bin/G3/gui.cgi?instance_i$\mathrm{d}=$ ocean_month). Salinity (PSU), dissolved oxygen $(\mathrm{ml} / \mathrm{l})$, and concentration of nitrate, phosphate, and silicate $(\mu \mathrm{mol} / \mathrm{l})$ were obtained from the World Ocean Atlas 2009 of the National Oceanic and Atmospheric Administration (NOAA; http://www.nodc.noaa.gov/ OC5/SELECT/woaselect/woaselect.html). Calcite concentration and $\mathrm{pH}$ were estimated using the program $\mathrm{CO}_{2} \mathrm{SyS}$ (http://carboocean.iopan.gda.pl/co2sys.htm), from data on temperature, salinity, silicate, nitrate and atmospheric concentration of carbon dioxide (obtained from the Scripps Institution of Oceanography $\mathrm{CO}^{2}$ Program; http:// scrippsco2.ucsd.edu/). Bathymetry (m) and coastal type (soft or hard bottom) were obtained from the Global Bathymetric Chart of the Oceans (www.gebco.net), and Google Earth, respectively. The modeling area was defined considering the known geographic range of the species, from $39.5^{\circ} \mathrm{N}$ to $-10.5^{\circ} \mathrm{S}$ of latitude, and from $-130.5^{\circ} \mathrm{W}$ to $-77^{\circ} \mathrm{W}$ of longitude for S. acapulcoensis and S. leucorus; and from $27^{\circ} \mathrm{N}$ to $17^{\circ} \mathrm{N}$ of latitude, and from $-116.5^{\circ}$
$\mathrm{W}$ to $-105^{\circ} \mathrm{W}$ of longitude for $H$. clarionensis. For modeling, in MaxEnt we used a maximum iteration value of 1000 and the logistic output to evaluate probability of occurrence of the species in each pixel in a scale of 0 to 1 representing the suitability of each pixel, being 0 unsuitable and 1 very suitable. By consensus, values of 0.5 and higher represent presence of the species at that pixel (Peterson et al., 2011). Model accuracy was determined with the area under the curve (AUC) of the threshold independent receiver operating characteristic analysis (ROC). Occurrence data were randomly partitioned into $75 \%$ for training and $25 \%$ for testing (Franklin, 2009).

\section{Results}

Based on the revised literature and consulted online collections we identified known locations where these species are distributed (Fig. 2). H. clarionensis summed 88 occurrence records, of which $68 \%$ belong to the Revillagigedo Islands (Mexican Pacific), $25 \%$ to the Gulf of California and less than $5 \%$ to islands above the $25^{\circ} \mathrm{N}$ (South-Californian Pacific). S. leucorus had 68 occurrence records, $75 \%$ to Revillagigedo Islands, $19.11 \%$ in the Gulf of California and 5.8 in insular environments

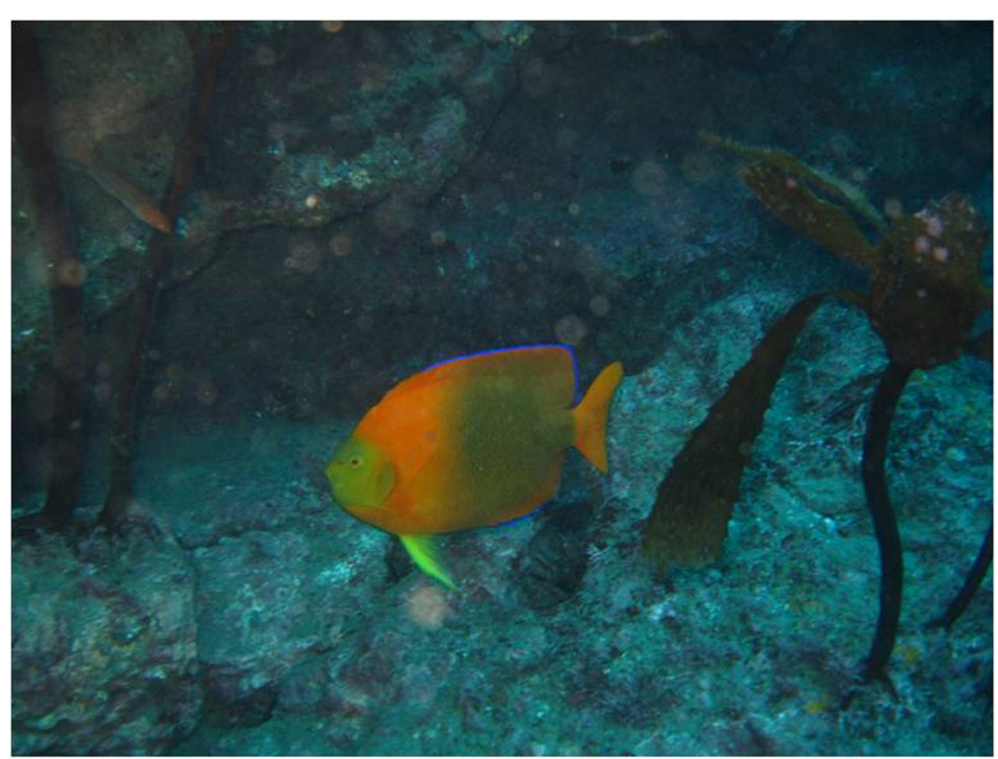

Fig. 3 Picture of $H$. clarionensis taken at one of the monitoring sites (Los cabitos) 
north of $25^{\circ} \mathrm{N}$. S. acapulcoensis had the highest number of records (358), with $9 \%$ in the Galapagos Islands, $66 \%$ in the Central American Pacific, $19 \%$ in the Mexican Pacific, and $5 \%$ in the Gulf of California.

The northernmost record for $H$. clarionensis is off the coasts of Baja California Sur, south of Almejas Bay $\left(24.25^{\circ} \mathrm{N}\right)$, while both Stegastes spp. have been recorded as far north as Los Cabos (23 ${ }^{\circ} \mathrm{N}$; Fig. 2). However, in our surveys we recorded these three species at georeferenced sites placed north of the putative limits (Table 2, Fig. 2), with extreme coordinates at $24.55777^{\circ} \mathrm{N}$, $112.10414^{\circ} \mathrm{W}$ at Magdalena Bay. No specimens of any of these species were reported during the monitorings from 2010 to 2013 (201 transects), and were only recorded in 2014 (Fig. 3). Visual censuses indicated that from the three species here reported, S. acapulcoensis was the most abundant, with mean densities of $0.125 \pm$ 0.125 ind/census, whilst $H$. clarionensis and S. leucorus presented densities of $0.042 \pm 0.042$ ind/census.

Niche models had a good performance according to the AUC, whose values in all three models were $>0.9$; considering that a random prediction has an $\mathrm{AUC}=0.5$. The species potential distribution maps (Fig. 4) indicated high occurrence probability for $H$. clarionensis at Revillagigedo Islands, where important populations are known to exist, and also where the majority of specimens with commercial purpose are extracted. S. acapulcoensis registered high probabilities at Galapagos
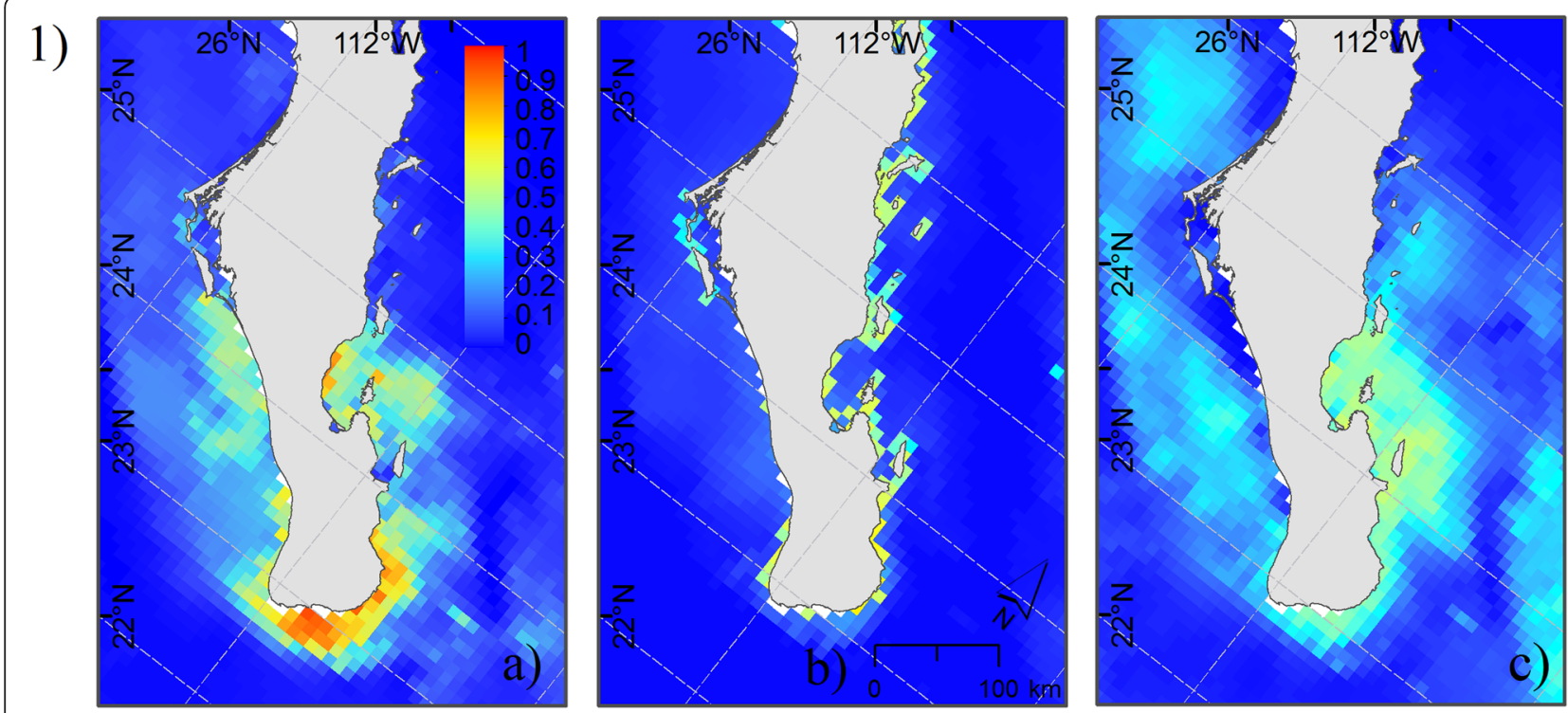

2)
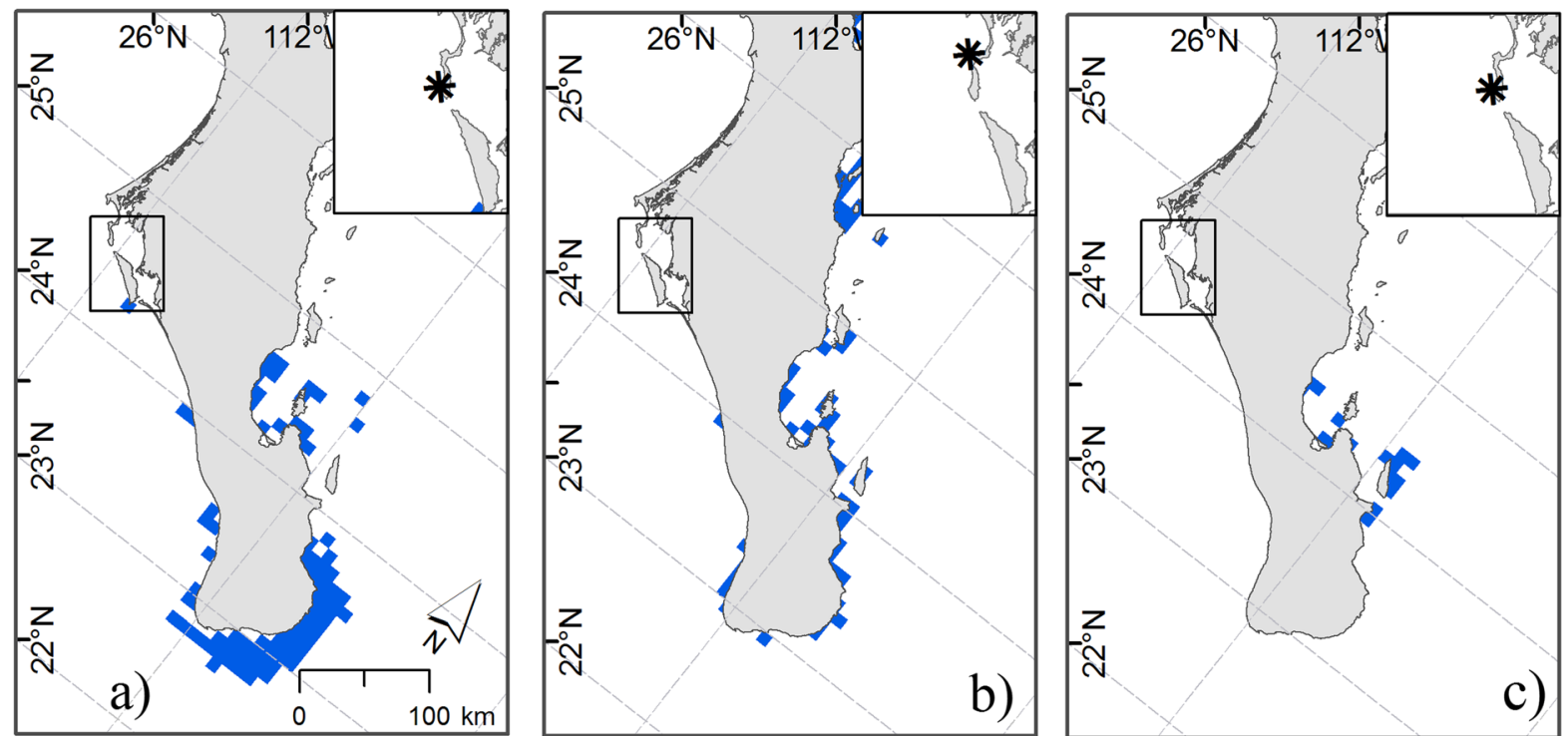

Fig. 4 Potential distribution at Baja California's coast of H. clarionensis (a), S. acapulcoensis (b) and S. leucorus (c) according to the MaxEnt model. 1) Probability of occurrence; 2) Presence-absence based on probability of occurrence values of 0.5 or higher. Asterisk indicates new records 
Island; additionally, S. leucorus also presented high probabilities at Revillagigedo Islands. At Magdalena Bay, the place of new records, the presence probability values for the three species were below 0.5 , denoting there are not ideal conditions for species occurrence/ or establishing.

\section{Discussion}

This is the first occurrence of H. clarionensis, S. leucorus y $S$. acapulcoensis at Bahia Magdalena. Presence of these species in the northern limit of the Tropical Eastern Pacific Province and previous records in Pacific islands might indicate a tendency in which tropical fish species are extending their ranges towards temperate environments. This tendency, also reported for species in the Gulf of California (González-Cuéllar et al., 2013; MartínezTorres et al., 2014; Fernández-Rivera Melo et al., 2015), might be explained by the warm water intrusions into northern regions reported for 2014 (Peterson et al. 2015).

The model outputs showed that bathymetry and coastal type were the most important variables limiting the distribution of the three species, in agreement with the preferred habitat characteristics preferred by Pomacanthids and Pomacentrids: rocky and coral reefs in shallow tropical and subtropical waters (Robertson \& Allen 2008). Nevertheless, the potential niche is determined by a series of biotic (e.g., food availability, predator abundance, competition) and abiotic (e.g., temperature, depth, salinity) factors, which allow a species to maintain a stable population (Peterson et al., 2011). Even though coast bathymetry and coast type requirements were met, other factors such as temperature, food availability and competition with native species may not allow these species to increment their abundances, and establish viable populations.

In conclusion, the results of this paper extend the currently known distribution northern endpoints for H. clarionensis, S. acapulcoensis, and S. leucorus. Low densities along with the absence of juveniles suggest that their reproductive populations have not established in Magdalena-Almejas Bay Complex. Nevertheless, currently rising temperatures and the confirmation of positive temperature anomalies during the possible 2015 El Niño event might promote their establishment.

\footnotetext{
Abbreviations

AUC, area under the curve; CITES, Convention of International Trade of Endangered Species of Wild Fauna and Flora; GBIF, Global Biodiversity Information Facility; GIOVANNI, Ocean Color Radiometry Online Visualization and Analysis Tool; IUCN, International Union for Conservation of Nature; NASA, National Aeronautics and Space Administration of the United State: NOAA, National Oceanic and Atmospheric Administration; OBIS, Ocean Biogeographic Information System; PSU, Practical Salinity Units; ROC, receiver operating characteristic analysis
}

\section{Acknowledgements}

We thank Roger Romero, Ernesto Romero, Norberto Estala, Raul Romero, Daniel Valdez, Ulises Gomez, Alberto de la Toba, Christian Alducin, and
Alfonso Romero for their support and participation in the monitoring of this work. Members of the fishing cooperative "Magdalena" provided invaluable help in the field.

\section{Funding}

This study was funded by David and Lucile Packard Foundation and Walton Family Foundation.

\section{Availability of data and materials}

Authors do not wish to share data used in this project, as it represents a subset of databases of private-owned (by fishers) no-take marine reserves. Nevertheless, data may be available upon contact of the main author, AHV.

\section{Authors' contributions}

AHV and FJFRM performed field surveys, SMMM performed the MaxEnt models, and JCVD managed the database and performed other analysis. All authors contributed equally to writing the paper. All authors read and approved the final manuscript.

\section{Competing interests}

The authors declare that they have no competing interests.

\section{Author details}

${ }^{1}$ Comunidad y Biodiversidad, A.C. Calle Isla del Peruano \#215 Col. Lomas de Miramar, Delicias, CP 85448 Guaymas, Sonora, Mexico. ${ }^{2}$ Instituto de Ciencias Marinas y Pesquerías, Universidad Veracruzana, Hidalgo 617 Col. Río Jamapa, C.P. 94290 Boca del Río, Veracruz, Mexico. ${ }^{3}$ Bren School of Environmental Science \& Management, University of California Santa Barbara, Santa Barbara CA 93106, USA.

Received: 7 June 2016 Accepted: 8 June 2016

Published online: 27 July 2016

\section{References}

Allen G, Robertson R. Fishes of the Tropical Eastern Pacific. University of Hawaii Press. Honolulu, Hawaii, USA. 1994. p. 335.

Allen G, Robertson R, Zapata F. Stegastes leucorus, The IUCN Red List of Threatened Species. (version 2014.3.). 2010a. Available at www.iucenredlist. org (Accessed 21 Feb 2015).

Allen G, Robertson R, Rivera R, Edgar G, Merlen G, Zapata F, Barraza E. Stegastes acapulcoensis, The IUCN Red List of Threatened Species. (version 2014.3.). 2010b. Available at www.iucenredlist.org (Accessed 21 Feb 2015).

Allen GR. Damselfishes. In: Paxton J, Eschmeyer W, editors. The world encyclopedia of fishes. 2nd ed. San Diego: Academic; 1998. p. 205-8.

Álvarez-Borrego S, Galindo-Bect LA, Chee-Barragán A. Características hidroquímicas de Bahía Magdalena, BCS. Cienc Mar. 1975:2:94-110.

Diario Oficial de la Federación. Norma Oficial Mexicana. México: NOM-059-ECOL2010; 2010. p. 78.

Eschmeyer WN, Fong JD. Species by family/subfamily, Catalog of fishes, California Academy of Sciences. (version 03/2015). 2015. Available at: http://research. calacademy.org/research/ichthyology/catalog/SpeciesByFamily.asp. (Accessed 21 Feb 2015).

Fernández-Rivera Melo FJ, Reyes-Bonilla H, Campos-Dávila L, Balart EF. Extension of range of Lutjanus inermis (Peters, 1896) (Perciformes: Lutjanidae) to the central region of the Gulf of California, Mexico. J Appl Ichthyol. 2015.

Franklin J. Mapping species distributions: spatial inference and prediction. Cambridge: Cambridge University Press; 2009. p. 320

Froese R, Pauly D, editors. FishBase. 2014 (version 11/2014).Available at: http:// www.fishbase.org (Accessed 21 Feb 2015).

Galván-Magaña F, Gutiérrez-Sánchez F, Abitia-Cárdenas LA, Rodríguez-Romero J. The distribution and affinities of the shore fishes of the Baja California Sur lagoons. In: Manuwar M, Lawrence SG, Manuwar IF, Malley DF, editors. Aquatic Ecosystems of Mexico: Status and Scope, Ecovision World Monograph Series. Backhuys Publishers; 2000. p. 383-98

Gardner SC, Chávez-Rosales S. Changes in the relative abundance and distribution of gray whales (Eschrichtius robustus) in Magdalena Bay, Mexico during an El Niño event. Mar Mamm Sci. 2000;16:728-38.

Global Biodiversity Information Facility. 2015. (version 2/2015). Available at: http:// data.gbif.org (Accessed 21 Feb 2015). 
González-Cuéllar OT, Reyes-Bonilla H, Fourriére M, Rojo M, Hernández-Velasco A Sánchez-Alcántara I, Pfister T. Range extensions of four species of parrotfishes (Scaridae) in the northern Gulf of California, Mexico. Cybium. 2013;37:223-6.

Humann P, de Loach N. Reef fish identification: Baja to Panama. Jacksonville: New World Publications; 2004.

Martínez-Torres M, Reyes-Bonilla H, Fernández-Rivera Melo FJ, Sánchez-Alcántara I, González-Cuellar OT, Morales-Portillo CD. Range extension of the blue and yellow damselfish Chromis limbaughi (Pomacentridae) to the northern Gulf of California, Mexico. Mar Biodiversity Rec. 2014;7:e43. doi:10.1017/ S1755267214000281.

Nelson JS. Fishes of the world. 4th ed. Hoboken: Wiley; 2006. p. 601.

Ocean Biogeographic Information System. 2015. 2015 (version 02/2015). Available at: http://www.iobis.org/ (accessed 21 Febrary 2015)

Peterson AT, Soberón J, Pearson RG, Anderson R, Martínez-Meyer E, Nakamura M, Araújo M. Ecological niches and geographic distributions. Princeton: Princeton University Press; 2011.

Peterson W, Robert M, Bond N. The warm blob - Conditions in the northeastern Pacific Ocean. PICES Press23.1; 2015. p. 36-8. Winter 2015. http://search. proquest.com/openview/481857b39c09789c693933a903bbde8a/1?pqorigsite $=$ gscholar.

Phillips SJ, Anderson RP, Schapire RE. Maximum entropy modeling of species geographic distribution. Ecol Model. 2006;190:231-59.

Piña-Espallargas R, Reyes-Bonilla H, Ortuño-Manzanares G, Garcáa-Náñez NE, Mendoza-Vargas L, González-Ania LV. Especies marinas de ornato del Golfo de California. In: Sustentabilidad y pesca responsable en México: evaluación y manejo. Mexico: INP-SAGARPA; 2001. p. 878-914.

Pyle R, Myers R, Rocha LA, Robertson R. Holacanthus clarionensis, The IUCN Red List of Threatened Species. (version 2014.3.). 2010. Available at www. iucenredlist.org (Accessed 21 Feb 2015).

Robertson RR, Allen GR. Shorefishes of the tropical eastern Pacific online information system. 2008 (version 1.0.4.53). Availble at: http://biogeodb.stri.si. edu/sttep/intro1.php (Accessed 21 Feb 2015).

Thomson DA, Findley LT, Kerstitch AN. Reef fishes of the Sea of Cortez. University of Texas Press, Austin, TX. 2000.

VerNet. 2015. (version 09/2014). Available at: http http://www.vertnet.org/ (Accessed 21 Feb 2015)

Wabnitz C, Taylor M, Green E, Razak T. From Ocean to Aquarium. 2003. UNEP-WCMC.

Zaitsev O, Sánchez-Montante O, Saldivar-Reyes M. Seasonal variations of the thermohaline structure in the Magdalena-Almejas Bay lagoon system and adjacent sea. Cienc Mar. 2010;36(4):413-32.

Zarate-Ovando B, Palacios E, Reyes-Bonilla H, Amador E, Saad G. Waterbirds of the Lagoon Complex Magdalena Bay-Almejas, Baja California Sur, Mexico. Waterbirds. 2006;29:350-64.

\section{Submit your next manuscript to BioMed Central and we will help you at every step:}

- We accept pre-submission inquiries

- Our selector tool helps you to find the most relevant journal

- We provide round the clock customer support

- Convenient online submission

- Thorough peer review

- Inclusion in PubMed and all major indexing services

- Maximum visibility for your research

Submit your manuscript at www.biomedcentral.com/submit

CBiomed Central 